\title{
ANALYSIS AND ASSESSMENT OF VIEWS UNDER THE CONSIDERATIONS OF HISTORICAL URBAN LANDSCAPE (HUL). CASE STUDY CUENCA, ECUADOR
}

\author{
C. Rodas ${ }^{1}$, S. Vintimilla ${ }^{1}$, S. Astudillo ${ }^{1,2}$ \\ ${ }^{1}$ Proyecto Ciudad Patrimonio Mundial, Facultad de Arquitectura y Urbanismo, Universidad de Cuenca, Av. 12 de Abril, Ciudadela \\ Universitaria, Cuenca, Ecuador - cm.rodasv@gmail.com, silvana.vintimilla@ucuenca.edu.ec \\ ${ }^{2}$ PhD Candidate Universidad Nacional del Cuyo, Argentina - sebastian.astudillo@ucuenca.edu.ec
}

\section{Commission II, WG II/8}

KEY WORDS: Relevant views, landscape, participatory analysis, assessment, images

\begin{abstract}
:
The cities have developed over time responding to various urban dynamics, in this process have been configured representative images, product of the synergy created between the natural elements of the environment and those built by the communities. The analysis of visuals, materializes a landscape value, not evidenced at the time of planning and design projects for cities with value surroundings; you can take as an example those good practices that other countries have implemented to assess, preserve and protect views such as English Heritage (2011), London View Management Framework (2012) or View Protection Guidelines of the city of Vancouver (2011). The methodological analyzes the view in two stages: the first one strategic points of observation and view basins are identified and described as element integrators - what is seen, and through citizen participation accepts or does not accept the evaluation criteria; in the second, the view is evaluated through the relationship between quality and incidence, giving it an assessment of how fragile it is. The application of the methodology in the area known as El Ejido in the city of Cuenca - Ecuador, has resulted in a total of twentyeight visuals considered relevant. Nine of them, have been analyzed completely, evidencing that there is a view quality very High / High; nevertheless, they are affected by urban actions that generate that the incidence is High and therefore the fragility and vulnerability is greater.
\end{abstract}

\section{INTRODUCTION}

\subsection{Relevant views}

For the study of views -what is seen of a PUH-, it is necessary to define those that are relevant for the city, understanding them as representative and valuable images that are configured in space as a response to the symbiosis between the natural conditions of the environment, the conditions created by man and especially the recognition of the community, becoming elements that reveal the view richness of a landscape. To define a view as relevant involves identifying special features that convey the value of the landscape which is expected to conserve, however, their analysis can be quite subjective, so the methodology integrates citizen participation and analyzes the view through its scenic composition giving a quantifiable and objective value.

The present article proposes a participatory methodology for the analysis and evaluation of Relevant Views, whose objective is to preserve the scenic compositions representative of the city and that synthesize their patrimonial and landscape values; through the pilot implementation it is expected to check the validity and relevance of the methodology as a tool to assess, preserve and protect the heritage features of the landscape through the sense of sight primarily.

\section{STAGE 1: DEFINITION OF VIEWS}

\subsection{Observation points and view basins}

Observation points located the viewer in relation to the observed landscape, considering precise locations where singular images

\footnotetext{
${ }^{1}$ historically recurrent images: images that have become referent of the city; spaces, zones and / or elements constantly photographed with different purposes and by different actors, provoking a certain
}

are observed. To map observation points it will be necessary to map them, taking into account that:

1. They must be in public spaces of free access,

2. The places must be of recurrent use and easy to identify for the community,

3. The observations points of historically recurrent ${ }^{l}$ photographs will be included

Starting with identifying public spaces, and a tour of the area, locate points and angles of vision reference from which one could analyze:

1. The relevance of the space where the points is located,

2. The visibility of the landscape environment, continuity and strong visual connection with the environment,

3. The conformation and contribution to the character of the HUL

4. Natural, urban, architectural elements or with cultural associations recognized by the community,

5. Areas, spaces or representative forms of the city, bases on existing evaluation criteria,

6. Configuration of historically recurring images.

\subsection{Participatory analysis}

The participatory analysis includes the vision of the community in the definition, analysis and validation of visuals, through multiple appreciations, readings and identification or sense of belonging of a place, which will feed a radial narrative (Berger, 1987), that feeds on different ways of seeing in which the memory of the community is involved; and, although the process of defining visuals becomes as complex as it is broad and

monitoring; for example, a postcard of a city: Paris with the Eiffel Tower, Rio de Janeiro with the Christ of the Corcovado, or the urban profile of New York, among others.

\footnotetext{
* Corresponding author
} 
subjective, it will allow collective memory to be included as a special factor for the recognition of the relevance of a visual. Through workshops and work tables with the community we expect to: obtain a collective symbolic visual perception; identify and validate, through visual perception, representative images of the urban landscape; identify relevant elements of the landscape that contribute to a greater degree to the understanding and configuration of the city, as well as those that are aggressive; determine material or immaterial elements that affect the integrity of the landscape.

Moreover, the use of social networks as a tool of participatory analysis is focused on the people who live in the city, with the aim of sharing from their perspective, spaces or compositions views they consider valuable, which represent or summarize the idea of what the city is.

\subsection{Qualitative View Evaluation (QVE)}

The EVC highlights the special characteristics to select the visual as relevant, highlighting its elements of architectural, urban, natural and historical-cultural interest, in order to establish the importance, value and meaning for those who observe it. The EVC clearly and objectively describes what is observed -in the image-, using it as a footprint of the landscape and not as an interpretation or imitation of it (Berger 1987), making an approximation that shows what is and what is does not mean (Sontag 1977), provides consistent information to evaluate the impact that future projects could produce on it. Each image analyzed contains a specific narrative about the landscape, and the radial relationship (Berger, 1987) between photography, memory and the construction of experience, feeds a story with a huge number of associations, turning the QVE into an exhaustive analysis process.

A matrix identifies the elements that make up the visual according to the plane of approach: close-up, closer to the observer, will identify greater detail in the compositional elements; second plane, -more distant and not be observed in great detail the elements that comprise it-, however it will be possible to identify the compositional elements that stand out; third plane, - it frames the image and places it in a general context, in a more diffuse way than in the previous one, it will mainly identify large shapes and colors.

\section{STAGE 2: VALUATION OF VIEWS}

\subsection{Assessment of Relevant Views (ARV)}

The notion of Historical Urban Landscape contemplates analyzing the landscape in a holistic way, considering the elements that configure it as a whole, as a stratification of layers that consolidate it and transform it over time. Considering this reflection, the ARV is proposed, as a means to evaluate the

\footnotetext{
${ }^{2}$ Buildings emerging value (E) by their historical characteristics or rich, scale or special meaning for the community, meet an exceptionally dominant role.

Buildings value Architect or single A (VAR A): Buildings that meet a constitutive role in the morphology í to stretch, apple or to rea in which are inserted, for their aesthetic, historical, or its social significance, have outstanding values.

Buildings value Architect or single B (VAR B): Its role is to consolidate a coherent fabric with the aesthetics of the city or area where they are located and can be enriched by historical attributes or important meanings for the local community. From the point of view of their spatial organization, they clearly express ways of life that reflect the culture and the use of community space.

Buildings Environmental Value (A): S and feature enable and strengthen a consistent readability of the city or to area in which they are located. These are measurements whose aesthetic, historical or scale
}

landscape not only from the natural or urban point of view, but also heritage and historical-cultural through an approach to quality, incidence and fragility view, whose evaluation is concentrated in the aesthetic sense, in the composition of the image through forms, colors, textures of the territory; in the spatial and visual expression of the medium as a set of physical characteristics perceptible to the eye.

The assessment is established on a qualitative scale (very high, high, medium, low or very low), which responds to the approach of Domingo Gómez Orea in the general methodology for environmental impact assessment (Astudillo et.al., 1998), in which the assessment parameters consider a greater number of intervals and elements analyzed, which are closer to the observed reality; that is, the scale will allow, through a greater number of segments or ranges of measurement, to locate the value of the visual in different degrees ( 5 -very high, high, medium, low, very low- and not only 3 -high, medium, low-).

The resulting variables crossing analysis established parameters for quality and view impact, will bring out the fragility of both of the view and landscape; consequently, they are the values of quality and incidence, they will determine the need of conservation of the visual characteristics of a landscape and the resulting level of fragility will give guidelines to define strategies, norms or ordinances for the urban design, architectural and landscaping.

\subsection{What is view quality?}

The view quality of a landscape is the merit or value of the view resource that according to each case can achieve merit or not to be conserved; it is given by the composition of the image according to the relation and integration between the elements that configure it , and it is evaluated by means of its components and visual and emotional characteristics that qualify the beauty of the landscape (Cifuentes, 1979); The variables considered are related to architectural, urban, natural and historical-cultural elements.

3.2.1 Evaluation of architectural elements: Considering the valuation categories ${ }^{2}$ of buildings and public spaces of the Ordenanza para la Gestión y Conservación de las Áreas Históricas y Patrimoniales del Cantón Cuenca (Municipio de Cuenca, 2010), the methodology proposes the following evaluation of the selected images:

VERY HIGH (3): Image dominated by buildings of Emerging value that make up the central axis, its importance and representativeness are clearly expressed. The environmental buildings are complementary, while those without value are not protagonists or obstruct the visibility of valuable elements.

HIGH (2): Emerging Buildings of value not observed very clearly, meanwhile the buildings VAR A or VAR B are protagonists and the environmental value complement the

characteristics do not stand out in a special way, fulfilling a complementary role in a global reading of the city. Its material characteristics, technology used for its construction and spatial solutions strongly reflect the expression of popular culture.

Buildings without special value (SV): Their presence lacks particular meanings for the city. Despite not being an expression of the local architectural tradition, they do not exert a de-configurative action that significantly affects the urban form. Its integration is admissible.

Buildings Negative Impact $(\mathbf{N})$ : Buildings, for reasons of scale, technology used, lack of aesthetic qualities in its conception, impair the urban image of the city or area in which they are inserted. Its presence constitutes a sensitive affection to the urban morphological coherence. (GAD Municipal del Cantón Cuenca, 2010) 
composition. The buildings without value or of affection will not be central or will hinder the visibility of valuable elements.

MEDIA (1): Buildings of environmental value dominate the visual. Buildings of Emergent value, VAR A or VAR B are not identified, or they are very diffuse or distant. The presence of buildings without value and / or affection, should be minimal and without obstructing the visibility of the scenic background.

LOW (0): The image is dominated by buildings with no value, the emergence of buildings in the landscape environment is clearly visible and, although in a second plane, buildings of affection can be seen.

VERY LOW (-1): In the foreground and dominating the image buildings with no value and / or affection are observed and could be obstructing the visibility of buildings of value or the environment.

3.2.2 Evaluation of urban elements: Welcoming the classification categories of public spaces of the city, raised in the "Metodología para la Catalogación y Valoración del Patrimonio del Espacio Urbano y Paisajístico de Cuenca" (Costa et. Al. 2009), is considered the valuation of urban elements, as described below:

VERY HIGH (3): Spaces that, for their aesthetic quality, historical memory and authenticity, are testimonies unique in themselves and in relation to their environment. They are configurators of the plot and the image of the city and are observed without obstructions and complementing with the architectural elements.

HIGH (2): Spaces that, due to their aesthetic, material, constructive or other relevant characteristics, which, without being unique elements, constitute important examples of significance within the city. Your visibility will not be obstructed by architectural elements without value.

MEDIA (1): Spaces that allow a coherent reading of the space, or that, without possessing relevant qualities, are part of groups or sectors of unique environmental quality that blend into the urban layout and its surroundings.

LOW (0): Spaces that have lost much of their original characteristics; although their presence is not significant, because of their location in the urban area they can contribute to the recovery of memory and the consolidation of the environmental and historical richness of the environment. The urban infrastructure is observed interrupting the visibility of elements of interest.

VERY LOW (-1): Degraded spaces or with altered use; they can be observed as a visual condition dominating the image or obstructing the visibility of valuable elements or the environment, altering the general reading of the landscape. It will be reflected in a track layout that generates conflicts in vehicular traffic or a disorderly housing site.

3.2.3 Evaluation of natural: The natural elements that are considered: vegetation water systems and mountainous profiles. The vegetation observed may belong to public or private spaces, considering that small isolated spots of one will grant less value to the visual than large vegetable beds normally identified in public spaces, charging -the spaces- greater meaning and valuing the importance of establishing a relationship between space and people in them (González de Canales 2004). The vegetation is a means to improve the conditions of physical and mental life of the population, including the criteria of selection, organization and implementation will allow the satisfaction of environmental, morphological, symbolic requirements, among others, and accordingly, improves the quality urban aesthetics. On the other hand, it is necessary to consider that not always the presence of vegetation guarantees a good scenic quality. The following evaluation is considered:
VERY HIGH (3): The vegetation and water systems dominate the visual. The vegetation is abundant and compact, letting it be seen a harmonious relationship with their urban environment and does not interrupt the visibility of items of value. The composition of the visual can show the scenic profile as a scenic background.

HIGH (2): The presence of water courses is not necessarily identified, but the vegetation, especially of public spaces, largely shapes the visual, generating harmony, balance and integration between the urban and natural environment.

MEDIA (1): The mountainous profile is identified clearly and vegetation in public or private spaces is dispersed, however, are considerable plant generate solid and harmony between the urban and natural elements $\mathrm{s}$, architectural.

LOW (0): The vegetation is scattered; its presence breaks the urban environment and although in a small amount its presence is noticeable.

VERY LOW (-1): The vegetation is reduced to small isolated areas that are almost imperceptible and the mountainous profile is not visible.

3.2.4 Evaluation of historical-cultural elements: Valuing the historical-cultural elements can become a complex task, referring to intangible aspects, that always have a scenario that houses them; that is to say, the historical-cultural facts are developed in a physical space or leave, as a witness, memorial element (monuments or plates). The importance of these elements is valued based on the representativeness for the community and the assessment that is granted does not represent the same weighting as the urban, architectural or natural elements. It is considered that in assessing historical and cultural facts represented in material elements, and on their intangible value, not in importance as a material element, valuing them as follows:

VERY HIGH-HIGH (2): Within the visual area, urban spaces or elements linked to historical events or cultural representations such as streets, squares, bridges, monuments or churches are clearly seen or even dominating the image.

MEDIA (1): In the visual, elements linked to historical or cultural events, such as bridges, churches, squares, among others, are identified in an isolated way and without dominating the image.

LOW-VERY LOW (0): The elements linked to historical or cultural events, these are practically imperceptible.

\subsection{Evaluation of the view as a whole}

It is possible that not all the aforementioned elements are observed in the image, which does not imply that the quality of the visual is greater or lesser. The quality of the view as a whole will be determined by the synergy of value factors; in this sense, the configuration of the visual has a meaning for the community (identified in the participatory analysis), beyond just being a composition of elements, textures and colors, considering the following evaluations:

VERY HIGH (between 11 and 9 points): Visual with potential to be important and representative at the local, national and international level for expressing in its composition unique characteristics and summarizing the meaning of the city. These are visuals with the greatest recognitions in participatory analysis, since all the elements interact with each other, especially with high evaluation, in their composition. All or almost all the elements analyzed are identified and if there are negative or affect elements, they do not dominate the image or they are almost imperceptible.

HIGH (between 8 and 6 points): Visual with potential to be important and representative at the local and national level for expressing in its composition unique characteristics and together 
summarize the meaning of the city. The image shows buildings of Emerging value (E), VAR A, VAR B and / or environmental, urban and natural value elements, whose heritage importance is clearly reflected in a harmonious composition with the environment. If there are elements of affection or without value, they must be mimicked or integrated into the environment.

MEDIA (between 5 and 3 points): View with the potential to be representative at the local level by expressing in its composition characteristics of the city's value and containing VAR A, VAR B, environmental, valueless and urban and / or natural elements. The value characteristics of the buildings are not represented with great quality, but their identification is achieved; if there is obstruction of the visual, the percentage of the obstruction should be considered on the surface of the image. LOW (between 2 and 1 point): Although buildings, urban and / or natural elements of value are identified from the observation point, they are obstructed by elements without value or affection. In the composition of the image or breaking the urban profile dominate elements of affection.

VERY LOW (between 0 and -3): The visual can show elements of environmental value, without value or affection, urban and / or natural elements with some obvious condition, or it can be partially or totally obstructed. If there are elements of value, they do not occupy the first or the second observation plane or the main axis of the image, however, their meaning is still represented.

\subsection{What is view incidence?}

The view incidence evaluates the frequency with which a detected area is viewed from a series of observation points; also it refers to the ability to be observed visually unobstructed (Cordero and Peñaherrera, 2017), and establishes how much you can see a landscape and how you can positively or negatively affect the presence of an element or. The degree of visual impact is determined by the analysis of variables, through the use of a SIG, which highlights the frequency and view intrusion, measured through a scale that considers its particularities. The crossing of these variables determines the visual incidence:

\begin{tabular}{|c|c|c|c|c|c|c|}
\hline \multicolumn{2}{|c|}{$\begin{array}{c}\text { Determination of visual } \\
\text { incidence }\end{array}$} & \multicolumn{5}{|c|}{$\begin{array}{l}\text { VISIBILITY } \\
\text { FREQUENCY } \\
\end{array}$} \\
\hline & & $\begin{array}{l}\text { Very } \\
\text { high }\end{array}$ & high & Half & Low & $\begin{array}{l}\text { Very } \\
\text { low }\end{array}$ \\
\hline \multirow{5}{*}{$\begin{array}{l}\text { VIEW } \\
\text { INTRUSION }\end{array}$} & $\begin{array}{l}\text { Very } \\
\text { high }\end{array}$ & $\begin{array}{l}\text { VERY } \\
\text { LOW }\end{array}$ & $\begin{array}{l}\text { VERY } \\
\text { LOW }\end{array}$ & LOW & $\begin{array}{l}\text { VERY } \\
\text { LOW }\end{array}$ & $\begin{array}{l}\text { VERY } \\
\text { LOW }\end{array}$ \\
\hline & high & LOW & LOW & LOW & $\begin{array}{l}\text { VERY } \\
\text { LOW }\end{array}$ & $\begin{array}{l}\text { VERY } \\
\text { LOW }\end{array}$ \\
\hline & Half & HALF & HALF & HALF & $\begin{array}{l}\text { VERY } \\
\text { LOW }\end{array}$ & $\begin{array}{l}\text { VERY } \\
\text { LOW }\end{array}$ \\
\hline & Low & $\mathrm{HIGH}$ & $\mathrm{HIGH}$ & HIGH & $\begin{array}{l}\text { VERY } \\
\text { LOW }\end{array}$ & $\begin{array}{l}\text { VERY } \\
\text { LOW }\end{array}$ \\
\hline & $\begin{array}{l}\text { Very } \\
\text { low }\end{array}$ & $\begin{array}{l}\text { VERY } \\
\text { HIGH }\end{array}$ & $\begin{array}{l}\text { VERY } \\
\text { HIGH }\end{array}$ & HIGH & $\begin{array}{l}\text { VERY } \\
\text { LOW }\end{array}$ & $\begin{array}{l}\text { VERY } \\
\text { LOW }\end{array}$ \\
\hline
\end{tabular}

Table 1: Relationship between visibility frequency and view intrusion, for the determination of visual incidence. Source: Astudillo, 1998.

3.4.1 Visibility frequency: It determines which locations of the analyzed surface, are visible from an observation point, for an evaluation of the extent to which each area contributes to the perception of the landscape and to obtain certain global parameters that allow to characterize a territory in visual terms (Morlans, 2002). The visibility frequency is defined according to the visibility calculation by using a GIS tool. (Figure 1).

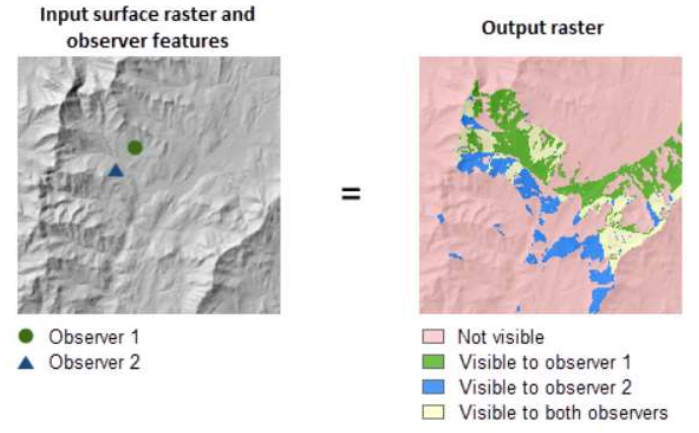

Figure 1. Visibility of a territory from an observation point. Source: https://pro.arcgis.com/es/pro-app/tool-reference/3danalyst/visibility.htm

The definition of the frequency of visibility allows and identify the most sensitive areas before the insertion of elements that excel in the visual, that is to say: the areas with greater visibility could be those of greater affection. Define the frequency of visibility as: VERY HIGH, HIGH, MEDIUM, LOW OR VERY LOW, responds to the percentage of visibility calculated within the visual basin, that is, how much can be observed from the visual basin -without obstructions- from a point of observation determined. The table below defines ranges according to the percentage of the observed territory:

\begin{tabular}{|l|l|}
\hline \multicolumn{1}{|c|}{$\begin{array}{c}\text { VISIBILITY } \\
\text { FREQUENCY }\end{array}$} & \multicolumn{1}{c|}{ DEFINITION } \\
\hline VERY HIGH & $\begin{array}{l}\text { If you observe more than } 60 \% \text { of the territory of the } \\
\text { visual basin analyzed }\end{array}$ \\
\hline HIGH & $\begin{array}{l}\text { If you observe between } 50 \text { and } 60 \% \text { of the territory of } \\
\text { the visual basin analyzed }\end{array}$ \\
\hline HALF & $\begin{array}{l}\text { If you observe between } 40 \text { and } 50 \% \text { of the territory of } \\
\text { the visual basin analyzed }\end{array}$ \\
\hline LOW & $\begin{array}{l}\text { If you observe between } 30 \text { and } 40 \% \text { of the territory of } \\
\text { the visual basin analyzed }\end{array}$ \\
\hline VERY LOW & $\begin{array}{l}\text { If less than } 30 \% \text { of the territory of the visual basin } \\
\text { analyzed is observed }\end{array}$ \\
\hline
\end{tabular}

Table 2: Definition of visibility frequency. Source: self made.

3.4.2 View intrusion: The view intrusion is the obstruction by elements that can present a visual and that therefore impede the reading of the environment; it is directly related to the location of the obstruction element, that is, if it is in the first, second or third observation plane, it will affect the visual analyzed to a greater or lesser degree. The table below defines ranges according to the percentage of the observed territory:

\begin{tabular}{|l|l|}
\hline $\begin{array}{l}\text { VIEW } \\
\text { INTRUSION }\end{array}$ & \multicolumn{1}{|c|}{ DEFINITION } \\
\hline VERY HIGH & $\begin{array}{l}\text { More than } 60 \% \text { of the territory of the visual basin is } \\
\text { obstructed by elements that stand out in the analyzed visual. }\end{array}$ \\
\hline HIGH & $\begin{array}{l}\text { A percentage between } 50 \text { and } 60 \% \text { of the territory of the } \\
\text { visual basin analyzed is obstructed by elements that stand } \\
\text { out in the visual }\end{array}$ \\
\hline HALF & $\begin{array}{l}\text { A percentage between } 40 \text { and } 50 \% \text { of the territory of the } \\
\text { visual basin analyzed is obstructed by elements that stand } \\
\text { out in the visual }\end{array}$ \\
\hline LOW & $\begin{array}{l}\text { A percentage between } 30 \text { and } 40 \% \text { of the territory of the } \\
\text { visual basin analyzed is obstructed by elements that stand } \\
\text { out in the visual }\end{array}$ \\
\hline VERY LOW & $\begin{array}{l}\text { Less than } 30 \% \text { of the territory of the visual basin is } \\
\text { obstructed by elements that stand out in the analyzed visual. }\end{array}$ \\
\hline
\end{tabular}

Table 3: Definition of view intrusion. Source: self made.

A visual will have a greater incidence when presenting less interruption and greater visual frequency; On the contrary, if the visual frequency is lower and the interruption is greater, the visual incidence will be lower. 


\subsection{What is view fragility?}

The fragility of a landscape is the susceptibility to change when an application or action on it develops, express to the degree of deterioration that it would experience before the impact of certain actions (Cifuentes, 1979).

While the visual quality of a landscape is an intrinsic quality of the territory, the fragility depends on the type of activity that takes place, and, it will be determined by the visual quality, as well as by its incidence; consequently, it depends on "what you see" and "how often or easily is it seen", that is how: the higher the quality and the higher the incidence, the greater the fragility. This analysis will give guidelines to define the vulnerability of the visual, or the aptitude that it has to absorb modifications or alterations without affecting its quality, then, if the visual one presents a high fragility, its capacity of visual absorption will be lower.

It has been decided to determine the visual fragility from the concepts of quality and visual impact, as proposed by Domingo Gómez Oréa, as shown below:

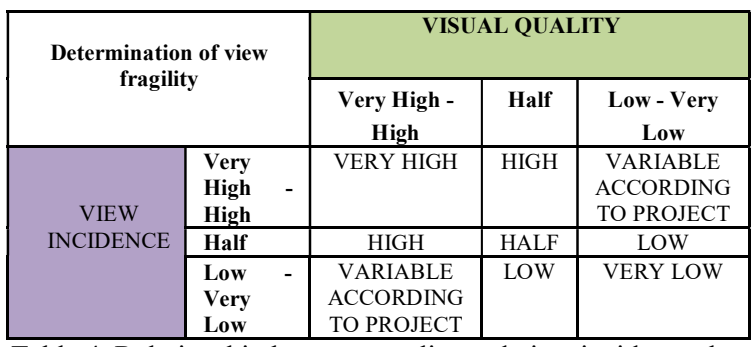

Table 4. Relationship between quality and view incidence that determines view fragility. Source: Own elaboration based on:

Astudillo, S. et. there; "Proposal Normative of use and occupation of the soil", taken from: Oréa Gómez, D.;

"Determination of Environmental Impacts"

\section{PILOT APPLICATION}

The study area established for the application of the methodology of analysis and assessment of relevant visuals is an urban area of the city of Cuenca, called El Ejido; space with characteristics of planning and different use from the historic area, and that currently houses several facilities that are part of the heritage of the city. The landscape value of the Ejido is given by the morphology of concentrating important elements including drainage, topography, vegetation, architecture, traditions, among others, and particularly visual, generated from and to the sector, which shows $\mathrm{n}$ special composition material and immaterial elements.

For the study, three areas have been considered (within the general study area), depending on the level of influence on the visuals, defined by historical components, urban planning, ordinances and collective memory. The first is the Specific Study Area limited to the east and west by urban elements -traditional neighborhoods-, which have marked the layout of the city and defined its entrance and exit even from the foundation, the northern and southern limits are marked by the Tomebamba and Yanuncay Rivers (see Figure 3). The second is the Area of Immediate Influence; they are areas adjacent to the previous area, located in higher or lower levels; and the third is the view influence area composed of the mountainous profile that surrounds the Ejido, integrated by the hills Icto Cruz, Cerro Monjas, Guagualzhumi, among others, - part of the circuit of sacred places in the city -, related to ceremonial, defense and lookout places (Astudillo, 2017, p54), being also landmarks or symbolic referents.

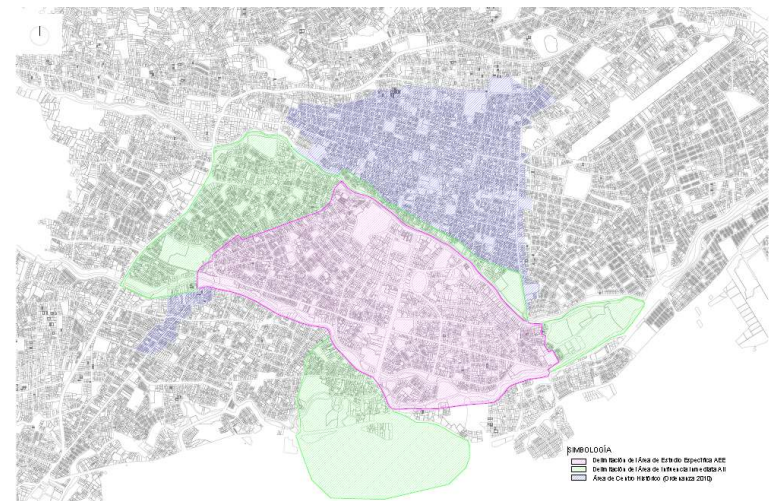

Figure 3. Delimitation of study areas. Source: self made

\subsection{APPLICATION STAGE 1:}

4.1.1 Identification of observation points: Delimited the study area, are located public spaces -parks, squares, linear parks, public green areas, etc.-, identified as possible points of observation. With the cartography of public spaces, tours are made to identify observation points and visual basins. It should be noted that not all public spaces have visual observation points of interest as the visual $\mathrm{s}$ is from or to El Ejido must contain elements n: value architectural, urban, historical-cultural and natural.

In addition to the mapping of the points, the information of each use is recorded in index cards with general data fieldsgeographical locations, codes, addresses and references.

4.1.2 Definition of visual basins: Located the observation points, the visuals are captured using a camera and a tripod. The application form registers two fields that define the visual basins, indicating angles of vision, directions and horizon. In addition, general data of the photographic equipment is recorded, which must capture all the visuals of the study.

Figure 4 corresponds to a plane with 22 identified observation points and 28 visual points; several of them belong to the same point due to the larger field resulting from the no obstacles being present and the height where it stood.

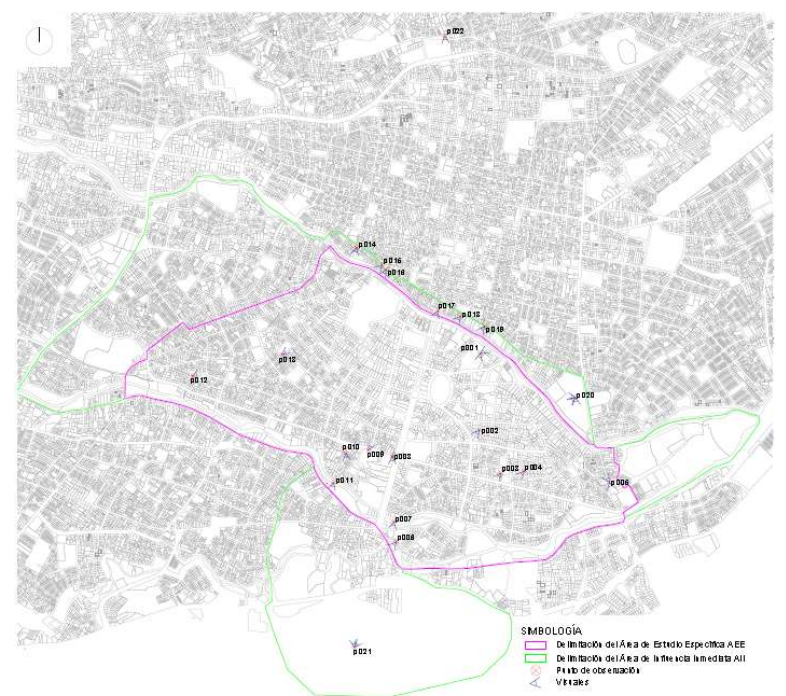

Figure 4. Location of observation points and visual basins. 
4.1.3 Participatory Analysis: The Participatory Analysis was developed in two stages; the first, through an experience with the community in a participatory workshop called: "The landscape of Cuenca, a look at construction" in 2016, focused on the identification of elements of collective interest, the extent to which its integrity affected and the actions to be carried out in order to face said threats (Cardoso, 2017). The workshop showed the importance of what the citizen observes and how collective memory is constructed through the spatial composition of groups. The second stage included the use of social networks (Facebook as an analysis tool), obtaining answers to:

1. What is your favorite image of the city and why? 2. Share with us your favorite photo of the city (old or current), the one in which, according to your opinion, it summarizes or represents what your city is.

The shared images were 28, which contain architectural, urban and natural elements, denoting above all milestones of interest recognized by the citizens through the first participatory workshop (see Figure 5). The result was a total of 31 votes in response to the first question; the photographs with the highest voting were 9 with similar appreciations, highlighting natural and architectonic heritage values; With the second question, 5 photographs of trails and bridges located on the Tomebamba river, valued as important due to their natural content, were shared.

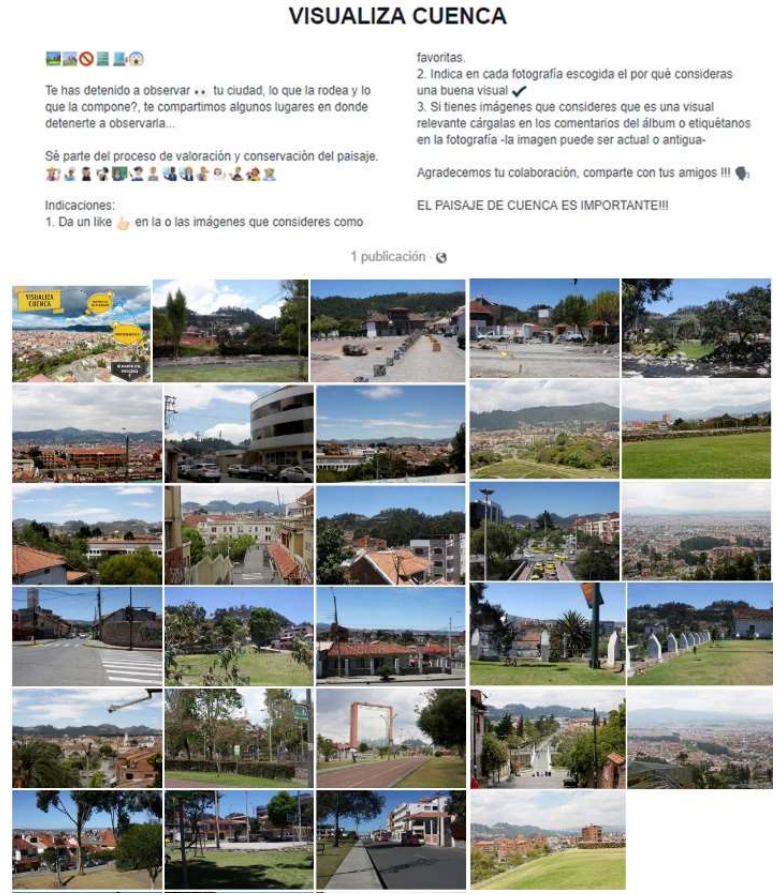

Figure 5. Views published on social networks Facebook.

4.1.4 Qualitative View Evaluation (QVE): The QVE describes the elements that compose the visual according to the observation plan, determining the existence of elements of Emerging value, VAR A, VARB, environmental, without value, new building and affection; in terms of urban areas, the presence of parks / squares, roads / bridges, parterres / round about and monuments are identified; the natural component registers the existing topography, hydrography and vegetation; and finally the historical-cultural elements, both material and immaterial.

In Figure 6, the division of planes of one of the analyzed visuals is shown (p014_01), which will be analyzed in the Valuation Stage.

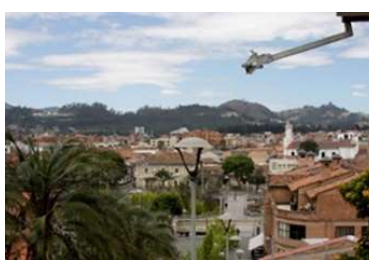

View p014_01

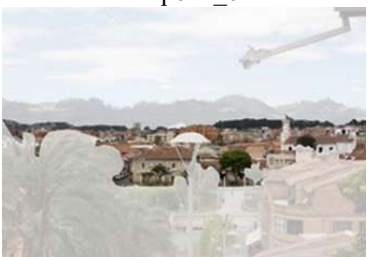

Second observation plan

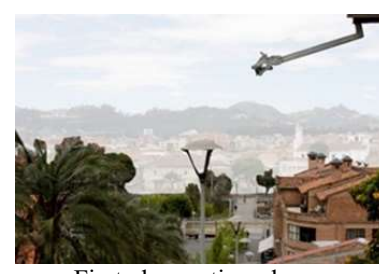

First observation plan

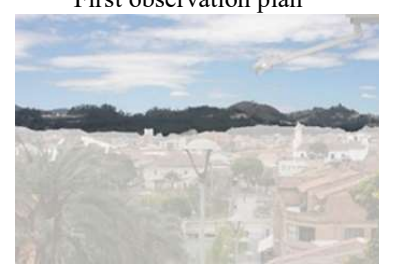

Third observation plan
Figure 6. Division by observation planes.

The QVE records the following information in the file shown in table 5:

- Elements of interest Arquit ectónico: Church of San Roque, Church of Turi, heritage buildings of Barrio San Roque, worthless buildings and affection for its height and volume, stationed in El Ejido, next to the Church of Turi.

- Elements of Urban interest : Plaza and Puente del Otorongo, Old Plaza del Carbón, Calle del Farol.

- Natural elements of interest: Mountainous profile of the hill of Turi, Monjas and El Calvario; Tomebamba river; vegetation on river banks, plazas, buildings and sidewalks; and mountain vegetation.

- Historic-cultural elements of registered interest: Presence of sacred mountains.

\subsection{APPLICATION STAGE 2:}

4.2.1 View Quality Analysis: The view analyzed has a visual quality HIGH (see Table 6) for its composition, which integrates vegetation, hydrographic (river Tomebamba), buildings value Emergent and VARB; to this the mountainous profile in the third plan is added. Although there are buildings without value and affection does not generate greater obstruction. Therefore, the visual is considered:

... has the potential to be important and representative at a local and national level by expressing in its composition unique and representative characteristics of the city and together show or summarize what the city is. If there are elements of affection or without value, they must be mimicked or in some way integrated into the environment and must not dominate the first plane of observation of the image. There will be no elements that obstruct the presence or visualization of compositions considered of interest. (taken from the methodology).

\begin{tabular}{|c|c|c|c|c|c|}
\hline $\begin{array}{l}\text { ELEMENTS } \\
\text { VALORACIÓN }\end{array}$ & \begin{tabular}{|l} 
ARCHITECT \\
URAL
\end{tabular} & URBAN & NATURAL & $\begin{array}{l}\text { HIISTORICAL/ } \\
\text { CULTURAL }\end{array}$ & TOTAL \\
\hline VERY HIGH & & & 3 & & \\
\hline HIGH & & 2 & & & 2 \\
\hline HALF & 1 & & & & \\
\hline LOW & & & & 0 & 0 \\
\hline VERY LOW & & & & & \\
\hline
\end{tabular}

Table 6. Assessment of view quality. Source: self made. 


\begin{tabular}{|c|c|c|c|c|c|c|c|c|c|c|c|c|c|c|}
\hline \multirow{3}{*}{ OBSERVATION PLANES } & \multicolumn{5}{|c|}{ ARCHITECTURAL } & \multicolumn{4}{|c|}{ URBAN } & \multicolumn{3}{|c|}{ NATURAL } & \multicolumn{2}{|c|}{ HISTORICAL-CULTURAL } \\
\hline & EMERGENTE (E) & VARA YVARB & AMBEENTAL(AA) & $\begin{array}{l}\text { SIN VAAOQ/ } \\
\text { NUEVA EOFIF. }\end{array}$ & DEAFECCIÓN & PARS/ PLAZZAS & $\begin{array}{l}\text { TRACKS/ } \\
\text { BRIDGES }\end{array}$ & $\begin{array}{l}\text { SIDEWALLSS } \\
\text { ROUNDABOUTS }\end{array}$ & MONUMENTS & TOPOGRAPHY & HYOROGRAPHY & vegetation & MaterlaL & INMATERALL \\
\hline & & & & & & & & & & & & & & \\
\hline \multirow{5}{*}{$\begin{array}{l}\text { CLOSE-UP } \\
\text { PLANE }\end{array}$} & & & & \multirow{6}{*}{$\begin{array}{c}\text { Existence of } \\
\text { worthless } \\
\text { buildings }\end{array}$} & & \multirow{6}{*}{ Otorongo Plaza } & \multirow{6}{*}{$\begin{array}{l}\text { Otorongo } \\
\text { Bridge }\end{array}$} & & & & \multirow{6}{*}{$\begin{array}{c}\text { Tomebamba } \\
\text { river }\end{array}$} & \multirow{6}{*}{$\begin{array}{c}\text { Vegetation in } \\
\text { river bank, } \\
\text { trees in plaza, } \\
\text { lands and } \\
\text { sidewalks }\end{array}$} & & \\
\hline & & & & & & & & & & & & & & \\
\hline & & & & & & & & & & & & & & \\
\hline & & & & & & & & & & & & & & \\
\hline & & & & & & & & & & & & & & \\
\hline & & & & & & & & & & & & & & \\
\hline & & & & \multirow{6}{*}{$\begin{array}{l}\text { Existence of } \\
\text { worthess } \\
\text { buildings }\end{array}$} & \multirow{6}{*}{$\begin{array}{c}\text { Existence of } \\
\text { affection } \\
\text { buildings for } \\
\text { their height } \\
\text { and size }\end{array}$} & \multirow{6}{*}{$\begin{array}{c}\text { Antigua Plaza de } \\
\text { Carbón }\end{array}$} & \multirow{6}{*}{ Calle del Farol } & & & & & \multirow{6}{*}{$\begin{array}{c}\text { Vegetation in } \\
\text { plaza del } \\
\text { Carbón and } \\
\text { San Roque } \\
\text { Park }\end{array}$} & & \\
\hline \multirow{5}{*}{ SECOND PLANE } & & & & & & & & & & & & & & \\
\hline & & $\begin{array}{c}\begin{array}{c}\text { Heritage } \\
\text { buildings of }\end{array} \\
\text {. }\end{array}$ & & & & & & & & & & & & \\
\hline & $\begin{array}{l}\text { San Rogue } \\
\text { church }\end{array}$ & San Roque & & & & & & & & & & & & \\
\hline & & $d$ & & & & & & & & & & & & \\
\hline & & & & & & & & & & & & & & \\
\hline \multirow{7}{*}{ THIRD PLANE } & \multirow{7}{*}{ Turichurch } & & & & \multirow{7}{*}{$\begin{array}{l}\text { Buildings are } \\
\text { insierted in the } \\
\text { Turith hill and } \\
\text { create } \\
\text { affections by } \\
\text { their size and } \\
\text { height, do not } \\
\text { harmoniziz with } \\
\text { the heritage } \\
\text { building }\end{array}$} & & & & & \multirow{7}{*}{$\begin{array}{l}\text { Mountainous } \\
\text { skyline of Turi } \\
\text { Hill, } \text {, Injasas and } \\
\text { EI Cavario }\end{array}$} & & \multirow{7}{*}{$\begin{array}{c}\text { Mountain } \\
\text { vegetation }\end{array}$} & \multirow{7}{*}{$\begin{array}{c}\text { Sacred } \\
\text { mountains }\end{array}$} & \\
\hline & & & & & & & & & & & & & & \\
\hline & & & & & & & & & & & & & & \\
\hline & & & & & & & & & & & & & & \\
\hline & & & & & & & & & & & & & & \\
\hline & & & & & & & & & & & & & & \\
\hline & & & & & & & & & & & & & & \\
\hline
\end{tabular}

Table 5. Qualitative View Evaluation according to the components of each observation plane. Source: self made.

4.2.2 View Incidence Analysis:

- Assessment of visibility frequency: The visibility frequency analysis, obtained through the application of tools in ArcMap, is presented in figure $7 \mathrm{a}$; the area identified in yellow corresponds to $11 \%$ of the analyzed territory, that is to say visible surface. The value results correspond, according to the methodology, of a LOW valuation.

- Assessment of View Intrusion: Figure $7 \mathrm{~b}$ highlights the obstructed area with purple, with $67 \%$ being the value considered as VERY HIGH according to the methodology. The relationship between the two variables results in a VERY HIGH-HIGH visual incidence, as can be seen in Table 7.

\begin{tabular}{|l|c|c|c|}
\hline $\begin{array}{l}\text { VARIABLES } \\
\text { ASSESSMENI }\end{array}$ & LANDSCAPE & INTRUSION & INCIDENCE \\
\cline { 1 - 3 } VERY HIGH & & $\mathrm{X}$ & \\
\cline { 1 - 3 } HIGH & & & \\
\hline HALF & & & \\
\cline { 1 - 3 } LOW & $\mathrm{X}$ & & \multirow{2}{*}{$\mathbf{x}$} \\
\hline VERY LOW & & & \\
\hline
\end{tabular}

Table 7. Assessment of the frequency of visibility and visual intrusion, according to the graphic analyzes.
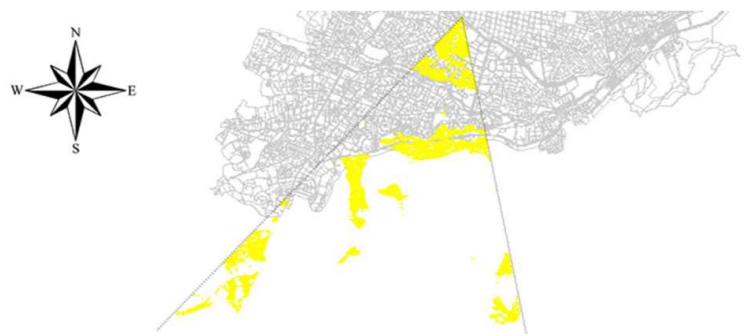

a. Visibility Frequency $11 \%$

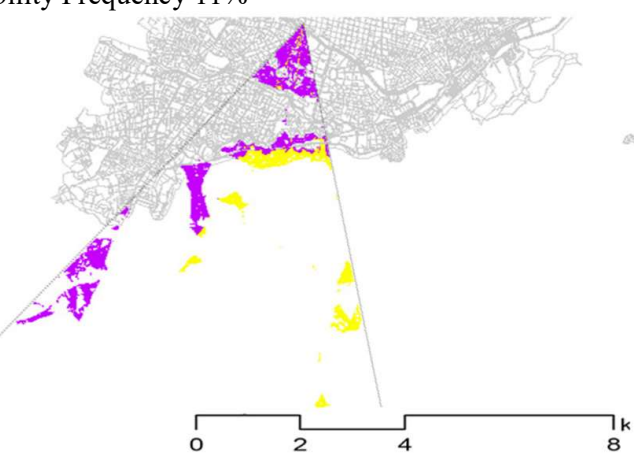

b. View Intrusion $67 \%$

Figure 7. a. Frequency of visibility analysis graphics. b. Visual intrusion analysis graph.

4.2.3 View fragility: Finally, it is determined that the visual is VARIABLE ACCORDING TO THE PROJECT (see Table 8), so any action should be analyzed through landscape studies, considering factors such as height and shape, scale and proportion, and materiality. 


\begin{tabular}{|c|c|c|c|c|}
\hline \multirow{2}{*}{\multicolumn{2}{|c|}{$\begin{array}{l}\text { Determination of } \\
\text { visual fragility }\end{array}$}} & \multicolumn{3}{|c|}{ VIEW QUALITY } \\
\hline & & Very High - High & Half & Low - Very Low \\
\hline \multirow{3}{*}{ 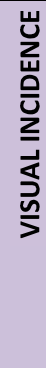 } & $\begin{array}{l}\text { Very High } \\
- \\
\text { High }\end{array}$ & VERY HIGH & $\mathrm{HIGH}$ & $\begin{array}{c}\text { VARIABLE } \\
\text { ACCORDING TO THE } \\
\text { PROJECT }\end{array}$ \\
\hline & Half & HIGH & HALF & LOW \\
\hline & $\begin{array}{l}\text { Low - } \\
\text { Very Low }\end{array}$ & $\begin{array}{c}\text { VARIABLE } \\
\text { ACCORDING TO } \\
\text { THE PROJECT }\end{array}$ & LOW & VERY LOW \\
\hline
\end{tabular}

Table 8. Evaluation of view fragility according to the crossing of the variables of quality and visual incidence.

\section{CONCLUSIONS}

The objective of the methodology, beyond analyzing relevant visuals, has been to create a tool for the assessment, conservation, protection and enhancement of representative images of cities; the accelerated urban development of recent times has put the cities of the world, depending on their scale, facing various transformations that in several cases have become aggressions; It is undeniable that the development and evolution of cities advances, however, it is important that urban planners consider the visual compositions that create unique and especially representative settings for the community.

The methodology has sought to be objective, but participatory analysis does not leave subjectivity in the assessment. The pilot application has shown that it guarantees the registration, analysis and appropriation of visuals that show material and immaterial values, but also evidence of affections and aggressions to the landscape.

Several visual protection processes have been analyzed based on their evaluation; To protect something it is necessary to know it in a profound way, in this sense the methodology has been able to analyze what is seen through its scenic composition, that is, each element contributes in the quality of the visual, as well as the location of the observation point It is directly related to the visual incidence and the synergy of elements evidences the fragility of the visual. Value each of these elements, to analyze the present and future of the city, and propose how to mitigate conditions and how to insert new project $\mathrm{s}$ to $\mathrm{s}$ and integrate harmoniously to their environment; considering the results of the analyzes and as a next step the development of general guidelines for the design and insertion of architectural or urban projects in environments of landscape value.

\section{REFERENCES}

Astudillo, S., Medina, W., Palacios, F., 1998. Propuesta normativa de uso y ocupación del suelo. Universidad de Cuenca, Cuenca, Ecuador.

Berger, J., 1987. Mirar. Hermann Blume, España, pp. 53, 61.

Cardoso, F., 2017. Discursos y experiencias para la gestión del patrimonio. Universidad de Cuenca, Cuenca, Ecuador, pp. 66101
Cifuentes, P., 1979. La Calidad Visual de Unidades

Territoriales. Aplicación al valle del rio Tietar. Tesis Doctoral. Universidad Politécnica, Madrid en: Solari, F., Cazorla, L. (2009). Valoración de la calidad y fragilidad visual del paisaje. https://fido.palermo.edu/servicios_dyc/publicacionesdc/vista/det alle_publicacion.php?id_libro $=14 \overline{4}$ (4 February 2019)

Cordero, S., Peñaherrera M., 2017. Incidencia de Alturas de las edificaciones en el Pisaje Urbano Histórico. Caso El Ejido en la ciudad de Cuenca. Universidad de Cuenca, Cuenca, Ecuador, pp. 92-94

Costa, C., Cordero, F., Pacají, G., 2009. Metodología para la catalogación y valoración del patrimonio del espacio urbano y paisajístico de Cuenca. Unviersidad de Cuenca, Cuenca, Ecuador, pp. 65.

English Heritage, 2011. Seeing the History in the View. https:// thegardenstrust.org/wp-content/uploads/2016/11/EH-Seeingthe-History-in-the-View-with-revision-note-2012.pdf (20 April 2019)

GAD Municipal del Cantón Cuenca. (2010). Ordenanza para la Gestión y Conservación de las Áreas Históricas y Patrimoniales del Cantón Cuenca. Cuenca-Ecuador http://www.cuenca.gob.ec/?q=node/8993 (8 June 2019)

González de Canales, C., 2004. El paisaje y los espacios públicos urbanos en el desarrollo de las sociedades https://www.miteco.gob.es/eu/ceneam/articulos-deopinion/2004_05priego_tcm35-163537.pdf (20 September 2018)

Hull, R., 1992. Brief encounters with urban forests produce moodsthat matter. Journal of Arboriculture. 18 (6): 322-324. In: González de Canales, C., 2004. El paisaje y los espacios públicos urbanos en el desarrollo de las sociedades https://www.miteco.gob.es/eu/ceneam/articulos-deopinion/2004_05priego_tcm35-163537.pdf (20 September 2018)

Morláns, M., 2002. El paisaje visual o paisaje percibido II http://editorial.unca.edu.ar/Publicacione\%20on\%20line/Ecologi a/imagenes/pdf/005-elpaisajepersibido-2.pdf (21 September 2018)

Sontag, S., 1977. Sobre la Fotografia. Editorial Debolsillo, Barcelona, España, pp. 135.

Updated to docx June 2019 